\title{
1 Differential host response to a herpesvirus: Marek's \\ 2 disease virus peptides on chicken MHC class II \\ 3 molecules are derived from only a few genes and \\ 4 illustrate a new mode of peptide binding
}

5

6

7
Samer Halabi ${ }^{1,2}$, Michael Ghosh ${ }^{3}$, Stefan Stevanović ${ }^{3}$, Hans-Georg Rammensee ${ }^{c}$, Luca D. Bertzbach $^{4}$, Benedikt B. Kaufer ${ }^{4}$, Martin C. Moncrieffe ${ }^{5}$, Bernd Kaspers ${ }^{6}$, Sonja Härtle ${ }^{6,}{ }^{*}$ and Jim Kaufman ${ }^{1,2,7, *}$

1. University of Cambridge, Department of Pathology, Tennis Court Road, Cambridge CB2 1QP, United Kingdom

2. University of Edinburgh, Institute for Immunology and Infection Research, Ashworth Laboratories, Charlotte Auerbach Road, Edinburgh EH9 3FL, United Kingdom

3. University of Tübingen, Department of Immunology, Institute of Cell Biology, Auf der Morgenstelle 15, Tübingen 72076, Germany

4. Freie Universität Berlin, Institut für Virologie, Robert von Ostertag Strasse 7-13, Berlin 14163, Germany

5. University of Cambridge, Department of Biochemistry, Tennis Court Road, Cambridge CB2 1GA, United Kingdom

6. Ludwig Maximillians University, Veterinary Faculty, Lena-Christ-Strasse 48, Planegg 82152, Germany

7. University of Cambridge, Department of Veterinary Medicine, Madingley Road, Cambridge CB3 0ES, United Kingdom

* corresponding authors

E-mail: sonja.haertle@1mu.de, jim.kaufman@ed.ac.uk

Short title: Only a few MDV peptides bound to MHC class II molecules 


\section{Abstract}

31 Viral diseases pose major threats to humans and other animals, including the billions of

32 chickens that are an important food source as well as a public health concern due to

33 zoonotic pathogens. Unlike humans and other typical mammals, the major histocompatibility complex (MHC) of chickens can confer decisive resistance or susceptibility to many viral diseases. An iconic example is Marek's disease, caused by an oncogenic herpesvirus with over 100 genes. Classical MHC class I and class II molecules present antigenic peptides to $\mathrm{T}$ lymphocytes, and it has been hard to understand how such MHC molecules could be involved in susceptibility to Marek's disease, given the potential number of peptides from over 100 genes. We used a new in vitro infection system and immunopeptidomics to determine peptide motifs for the two class II molecules expressed by the MHC haplotype B2, which is known to confer resistance to Marek's disease.

42 Surprisingly, we found that the vast majority of viral peptide epitopes presented by chicken 43 class II molecules arise from only four viral genes, nearly all having the peptide motif for BL2, the dominantly-expressed class II molecule in chickens. We expressed BL2 linked to several MDV peptides, and determined one X-ray crystal structure, showing how a single small amino acid in the binding site causes a crinkle in the peptide, leading to core binding peptide of ten amino acids, compared to the nine amino acids in all other reported class II molecules. The limited number of potential $\mathrm{T}$ cell epitopes from such a complex virus can explain the differential MHC-determined resistance to MDV, but raises questions of mechanism and opportunities for vaccine targets in this important food species, as well as providing a basis for understanding class II molecules in other species including humans. 


\section{Introduction}

The ongoing global pandemic of a coronavirus among humans highlights the enormous challenge of viral disease, and the importance of the appropriate immune responses [1-3]. The classical class I and class II molecules of the major histocompatibility complex (MHC) play crucial roles in resistance to infection and response to vaccines, binding peptides for presentation to thymus-derived (T) lymphocytes of the adaptive immune system as well as natural killer (NK) cells of the innate immune system $[4,5]$. The importance of the classical MHC molecules is underscored by their high level of allelic polymorphism, which is mostly driven by molecular arms races with infectious pathogens [5]. However, the MHC of humans and typical mammals is an enormous and complex genetic region encoding a wide variety of molecules, with multigene families encoding class I and class II molecules leading to strong genetic associations with autoimmune disease but relatively weak associations with infectious diseases [4].

In contrast to humans and other typical mammals, the level of resistance to many infectious pathogens in chickens can be strongly determined by the MHC (that is, the BF-BL region of the B locus), at least in part because the chicken MHC is much simpler, with single dominantly-expressed class I and class II loci $[6,7]$. As a result of this simplicity, the phenotypes are much clearer: either the dominantly-expressed MHC allele finds a protective peptide to confer resistance or not, leading to strong genetic associations that are easier to discover and dissect [7]. Moreover, the scale of viral challenges in the poultry industry has been clear for decades, with many tens of billions of chickens each year beset by a wide variety of poultry viruses [6], including the first coronavirus ever described as such [8]. On top of the economic importance, zoonotic pathogens (including avian influenza) have been a continuing concern for public health $[9,10]$. Despite enormous efforts in biosecurity, vaccination and genetic breeding, condemnation and slaughter of huge numbers of infected chickens are relatively frequent [11].

Among the economically-important diseases for which the chicken MHC is known to determine resistance and susceptibility, Marek's disease (MD) caused by an oncogenic herpesvirus was the first reported, is the best studied and remains an enormous burden for the poultry industry, with continuing outbreaks despite routine vaccination [12-16]. Indeed, current vaccines control disease but not transmission, leading to selection of more virulent strains, which in turn have required more efficacious vaccines [17, 18]. The virus responsible for MD (MDV), in common with other herpesviruses, has a relatively large genome with over 100 genes and a complex life cycle, so it is possible that many genes contribute to resistance at different stages of infection, tumor growth and transmission [14, 16]. Several polymorphic genes located in the MHC have been proposed as candidates to determine MD resistance, including the dominantly-expressed classical class I gene (BF2), an NK receptor gene (B-NK), a gene with some similarities to mammalian butyrophilins (BG1) and the classical class II B genes (BLB1 and BLB2) [19-25]. In comparison to the MHC class I system, very little attention has been focused on chicken class II genes and molecules $[7,26]$.

Mammalian class II molecules have been intensively studied, so many structural and functional features are known in detail [27-30]. The heterodimer is composed of an $\alpha$ and a $\beta$ chain, each with two extracellular domains: membrane proximal immunoglobulin C-like (Ig C) domains ( $\alpha 2$ and $\beta 2$ domains) and membrane distal domains composed of four $\beta$ - 
strands forming a $\beta$-sheet surmounted by predominantly $\alpha$-helical stretches $(\alpha 1$ and $\beta 1$ domains). The domain organization, including the features of secondary structure and location of intra-domain disulfide bonds, is similar to class I molecules. The membrane distal domains together form a peptide-binding super-domain, with a core sequence from the peptide binding across a groove, the $\mathrm{T}$ cell receptor recognizing the top, and the dedicated chaperone DM interacting with key residues on the side for loading of appropriate peptides. A glycosylation site near the end of the $\alpha 1$ domain is likely to be involved in quality control during biosynthesis and peptide loading (as in class I, [31]), while a loop in the $\beta 2$ domain and part of the $\alpha 2$ domain bind the CD4 co-receptor that contributes to T cell signaling (in the same place as CD8 interacts with class I, [30, 32]).

As in human HLA-DR molecules, the chicken $\alpha$-chain (encoded by the BLA gene) is nearly monomorphic, with most residues on the top of the $\alpha 1$ domain identical with DRA (although there is dimorphic position in the $\alpha$-helix pointing up towards the T cells, and a four amino acid insertion in one loop of the $\beta$-sheet) [33]. Virtually all of the variation responsible for allelic polymorphism and thus for different peptide-binding specificities in different chicken class II molecules is located in the $\beta 1$ domain of the $\beta$ chain, encoded by either the BLB1 or BLB2 gene $[34,35]$.

Differential immune responses by classical MHC molecules have typically been understood as $\mathrm{MHC}$ molecules either presenting a peptide that confers an effective immune response or not. However, a major concern is how classical MHC molecules could confer susceptibility to a virus such as MDV, since it is hard to imagine how a peptide conferring protection would not be found among 100 viral molecules [19]. This conundrum is particularly an issue for class II molecules for which the peptide motifs are relatively promiscuous compared to class I molecules [28]. A significant barrier to examining this question has been the low frequency of cells infected with MDV within chickens before tumors arise.

In this report, we use a novel culture system for bursal B cells [36], followed by determination of the peptides bound to class II molecules by mass spectrometry (so-called immunopeptidomics or MHC ligandomics, [37, 38]). We identify the peptides bound to class II molecules from the well-characterized MHC haplotype B2 known to confer resistance to MD $[13,39]$, with and without infection by the very virulent MDV strain RB$1 \mathrm{~B}$ (also known as RB1B, 40) and the live attenuated virus strain CVI988 (widely used as the Rispens vaccine, [41]). We then express the chicken class II molecule BL2*02 with several dominant pathogen peptides and determine the structure of one such complex by Xray crystallography to examine whether there are unusual molecular features that might help explain the biology of resistance. 


\section{Results}

Peptides from two class II molecules were found in bursal B cells from the B2 MHC haplotype

After one day in culture with and without infection, ex vivo bursal cells from the M11 chicken line were harvested, MHC molecules were isolated from detergent lysates by affinity chromatography, and the eluted peptides were analyzed by mass spectrometry. In experiments over three years, one uninfected sample, two samples infected with the live attenuated virus strain CVI988 and three samples infected with the very virulent MDV strain RB1B were analyzed.

Several thousand peptides were identified for each infected sample, with between $36 \%$ and $84 \%$ of a particular sample shared with other samples (Fig S1, Datasets S1-S6). Since rare peptides may not be sampled in repeated analyses, the high level of overlap between analyses gives confidence that most abundant peptides were likely to have been identified.

Overall, the sequences have the features typical of peptides bound by mammalian class II molecules, including an enrichment of proline around position 2 (due to the cleavage preference for aminopeptidases) and a broad distribution of length from 12 to more than 25 , with a peak around 16 to 17 amino acids (Fig S2, Datasets S1-S6). Initial analysis by Gibbs clustering identified two nonamer (9mer) core motifs in all samples, but subsequent structural evidence (detailed below) led to a re-analysis that showed one of these motifs to be a decamer (10mer) (Fig 1A). The two motifs turn out to represent the two classical class II molecules in chickens, BL1 and BL2, encoded by a monomorphic DRA-like A gene (BLA) and two polymorphic classical class II B genes (BLB1 and BLB2). At the RNA level, BLB1 is poorly expressed except in the intestine, while BLB2 is well expressed systemically [26]. However, the ratio of peptides from these ex vivo bursal B cells was around $40 \%$ nonamer and 60\% decamer in all samples (Datasets S1-S6).

Fig 1. Two peptide motifs are found for class II molecules from the MHC B2 haplotype, one of which is a decamer for which peptides lead to expressed class II molecules with high thermal stability. (A) peptide motifs determined by Gibbs clustering: upper panel with default length set to $9 \mathrm{mer}$, lower panel with default length set to $10 \mathrm{mer}$. (B) thermal denaturation curve for BL2 molecules expressed with three peptides that have decamer motifs (GVLFYMPTSHVQQMTF from $\mathrm{gH}$ with melting temperature $69^{\circ} \mathrm{C}$, QIESLSLNGVPNIFLSTKA from $\mathrm{gE}$ with $75^{\circ} \mathrm{C}$, SSEVLTSIGKPAQFIFA from UL43 tegument protein with $78^{\circ} \mathrm{C}$ ); the peptide TPSDVIEKELMEKLKKK from gI with a nonamer motif did not express. 


\section{Four MDV genes gave rise to most of the pathogen peptides bound to class II molecules from bursal B cells, with most bound to BL2 molecules}

Out of the thousands of peptides characterized, 23 epitopes from 17 MDV genes were identified, but most were found only in one sample and/or as only one species of peptide (Fig 2, Table 1, Table S1). However, multiple species of a single epitope and/or multiple peptide epitopes were found in several infected samples for four MDV proteins: glycoprotein $\mathrm{H}$ (gH, encoded by the MDV034 gene), UL43 tegument protein (MDV056), gI (MDV095) and gE (MDV096). Five peptide epitopes were found for gH, two of which had multiple species, of which one was found in all five samples. The UL43 tegument protein had one peptide epitope with 16 species, some of which were found in two to four samples. For gI, one peptide epitope was found with three species, one of which was found in four samples. For gE, two peptides were found, one of which had 18 species, four of which were found in all five samples.

Most of these peptide species had the decamer motif, including those from three of the four MDV proteins with abundant peptides. From the analysis by Gibbs clustering, eight peptide species from five epitopes fit the nonamer BLB1 motif, 45 species from ten epitopes fit the decamer BLB2 motif, nine species from six epitopes fit both motifs (and thus might actually contain two epitopes), and two species each from one epitope didn't fit either motif (Table 1).

Soluble BL2 molecules from the B2 haplotype were expressed in insect cells using Baculovirus, with the peptide attached via a linker to the BLB2 chain [it should be noted that, in contrast to previous reports [34, 42, 43], the N-terminal positions of the BLA and BLB chains are likely identical to those of HLA-DR (Fig S3)]. Confirming the assignments based on motifs, three peptide species with decamer motifs linked to BL2 molecules were successfully expressed, and the complexes had high thermal stabilities (Fig 1B). However, the one peptide with a nonamer motif that was tested did not produce a soluble complex with BL2, and therefore is likely to have been bound to a BL1 molecule on chicken bursal $\mathrm{B}$ cells.

Fig 2. Only four MDV proteins give rise to most peptides bound to class II molecules from infected chicken bursal $B$ cells in culture. Thin horizontal line indicates MDV genome of roughly $180 \mathrm{kB}$, with relevant MDV genes indicated by black boxes labelled with the number of the gene (for instance, MDV022) and with arrowheads indicating class II-bound peptides, above the line for genes and peptides oriented from left to right and below the line for right to left. Each vertical stack of arrowheads indicates a single T cell epitope with multiple peptide species (with the protein name next to the stack), each arrowhead colored according to the number of experimental samples in which the peptide species was found (blue, 1; green, 2; yellow, 3; orange, 4; red, 5). 
bioRxiv preprint doi: https://doi.org/10.1101/2020.11.27.400937; this version posted November 27, 2020. The copyright holder for this preprint (which was not certified by peer review) is the author/funder, who has granted bioRxiv a license to display the preprint in perpetuity. It is made available under aCC-BY 4.0 International license.

207 Table 1. Peptides from class II molecules of bursal B cells infected in vitro proteins and 208 peptides in order of the genomic sequence; blue, green indicate multiple species from same 209 peptide location; soluble BL linked with BLB2: * expressed, ** not expressed; peptide 210 species found in particular experiment indicated by 1.

MDV040/UL27 MDV046/UL32 MDV056/UL43

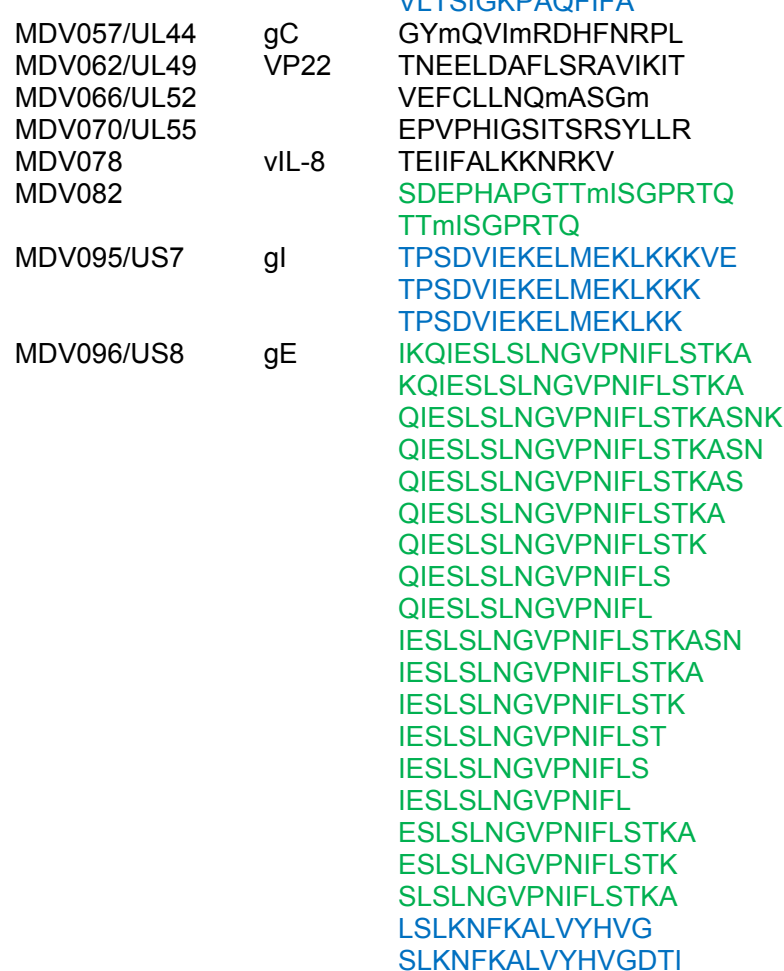

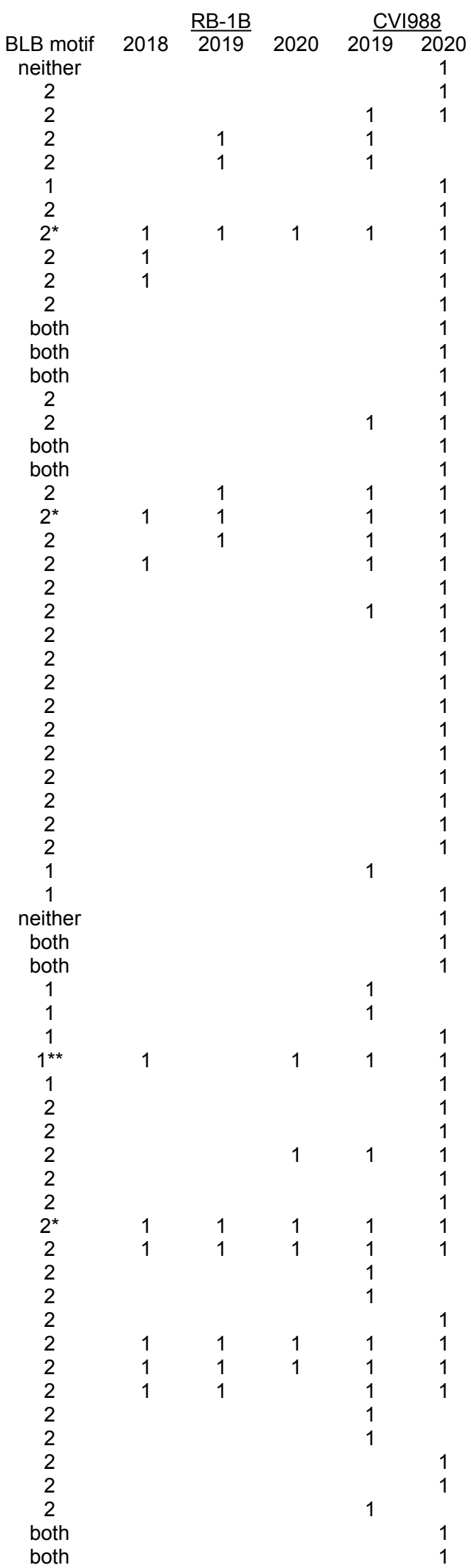


The overall structure of a chicken class II molecule is similar to those of mammals

213

214

215

216

217

218

219

220

221

222

223

224

225

226

227

228

229

230

231

232

233

234

235

236

237

238

239

240

241

242

243

244

Of the four soluble BL2 molecules from the B2 haplotype linked to MDV peptides that were expressed, the one with a peptide from $\mathrm{gE}$ formed crystals that diffracted to sufficiently high resolution to determine a structure (Fig 3A-C, Table S2). As this work was being written up for publication, a paper was published with the crystal structure of a ribosomal peptide in complex with a soluble BL2 molecule from B19 [43], an MHC haplotype known to confer susceptibility to $\operatorname{MD}[13,44]$.

Overall, the structure of BL2 from B2 (BL2*02) is extremely similar to BL2 from B19 (BL2*19) and to the iconic mammalian class II molecule HLA-DR1 (Fig 3D, E), with root mean square deviations for $\mathrm{C} \alpha$ atoms of 0.684 and $0.878 \AA$, respectively (Table S3). Most of the key residues found in mammalian class II molecules are identical in these three structures and found in nearly identical conformations, including those involved in domain folding (disulfide bonds and glycosylation site) and in inter-domain, DM and CD4 interactions (Fig 3E, Fig S4, Table S4). However, both chicken molecules have a four amino acid extension to the first loop and second $\beta$-strand of the $\alpha$ chain compared to HLADR1 (Fig 3D, [33, 43]).

\section{Fig 3. The structure of the chicken BL2*02 molecule with peptide} QIESLSLNGVPNIFLSTKA from gE is very similar to the BL2*19 molecule and the human DR1*01 molecule. (A) two side views of BL2*02 with peptide in ribbons; $\alpha$ chain and peptide, slate blue; $\beta$ chain, deep salmon red. (B) two side views of BL $2 * 02$ with peptide as solvent-accessible surface calculated by APBS electrostatics (positive charge, blue; negative charge, red). (C) Top view and side view (through $\beta 1$ domain omitted for clarity) of BL $2 * 02$ in ribbons and peptide in stick as a composite omit $\left(2 \mathrm{~F}_{\mathrm{o}}-\mathrm{F}_{\mathrm{c}}\right)$ map contoured at $1 \AA$ in blue chicken wire. (D) top view of $\mathrm{C} \alpha$ backbone of class II molecule with peptides superimposed, $\alpha 1$ domain above and $\beta 1$ domain below. Left panel: BL $2 * 02$, slate blue; DR $1 * 01$, grey; dotted circle indicates loop with four amino acid insert in chicken class II molecules. Right panel: BL2*02, slate blue; BL2*19, grey with peptide in yellow. (E) top view of a portion of the class II molecules superimposed in ribbons, $\alpha 1$ domain above and $\beta 1$ domain below, with key residues [W $\alpha 47(43), E \alpha 59(55), F \beta 89(89)]$ in sticks to show differences (including $3_{10}$ to $\alpha$-helix) upon DM binding. Left panel: BL2*02, slate blue; DR1*01, grey. Right panel: DR1*01 (PDB accession 4X5W), white; DR1*01 in DM co-crystal (4GBX), green; red arrows indicate major structural movements. 


\section{BL2 from B2 illustrates a new mode of peptide binding for MHC class II molecules}

246

247

248

249

250

251

252

253

254

255

256

257

258

259

260

261

262

263

264

265

266

267

268

269

270

271

272

273

274

275

276

277

278

279

280

281

282

283

284

285

286

287

288

289

290

The way in which peptides bind to mammalian class II molecules has been studied in detail, showing that a nonamer core binds as a polyproline II helix, with main chain atoms forming hydrogen bounds (H-bonds) with the MHC molecule and with three or four side chains binding into pockets that determine the specificity of binding between MHC alleles [27, 28]. Typically the bound peptides extend from the $\mathrm{N}$ - and $\mathrm{C}$-terminal of the core, permitted by an arginine found in all class II molecules and in the classical class I molecules of nonmammalian vertebrates and with these flanking regions sometimes assuming stable structures that can be recognized by T cells [27, 45-47]. In fact, the P10 side chain of a peptide with a nonamer core has been reported [48] in one structure to bind onto a polymorphic shelf outside of the groove (Fig S5).

In stark contrast to all reported mammalian class II structures and to BL2*19, the BL2*02 has a decamer core, with the structure showing side chains at peptide positions P1, P4, P5, P8 and P10 of the core binding into pockets, so that the peptides that were first analyzed with a nonamer motif were reanalyzed for this peptide motif (Figs 2A, 4A,B); the decamer sequence predicted by Gibbs clustering corresponded to the core sequence found in the struture. Compared to mammals and to BL2*19, the peptide in BL2*02 shifts the residues pointing up from the core towards the T cell from the typical P2, P3, P4 or P5 and P8 to P2, P3, P6 and P9, shifting register at P4 (Fig 4B). The class II residues that form H-bonds with the main chain atoms of the peptide were originally described for DR1 [27] and are identical in chickens (except for chicken $\mathrm{N} \alpha 80$ and Q $\beta 57$ which are R and D in humans, and I 371 in BL2*02 which is $\mathrm{R}$ in the other two structures), but again BL2*02 shifts register at $\mathrm{P} 4$, with subsequent interactions occurring one peptide position after DR1 and BL2*19 (Fig 4D). However, current analyses of such bonding are more refined, with some residues interacting through waters and other polymorphic residues contributing to main chain peptide interactions (Figs S6-S8)

The conformation of the peptide bound to BL2*02 shows a polyproline II helix as in mammals, but deviates downwards just at $\mathrm{P} 4$ and then returns to the helical conformation (Fig 4C). Comparing the peptides from the side view confirms that it is peptide position P4 that is located lower in the groove than in other reported class II peptides (Figs 3D, 4B,E,F). This "crinkle" in the peptide is due to a single BLB residue Ser $\beta 78$ in BL2*02 that leads to a deeper pocket compared to Phe $\beta 78$ from BL2*19 and Tyr $\beta 78$ from DRB1, and which pulls P4 downwards and pulls the main chain register towards the N-terminus of the peptide, resulting in the decamer core (Fig 4B,E). Comparison of the contacts around P4 shows that this relatively small residue Ser $\beta 78$ accommodates the peptide in the conformation adopted in BL2*02, while larger residues Tyr $\beta 78$ in DR1 and Phe $\beta 78$ in BL2*19 would conflict (Fig $4 \mathrm{~F})$.

Fig 4. Although similar in overall structure to other class II molecules, BL2*02 binds peptides with a decamer motif due to Serß78. A-C. top panels, BL2*02 (PDB accession 6T3Y); middle panels, BL2*19 (6KVM); bottom panels, DR $1 * 01$ (1DLH). (A) top view of solvent-accessible surface of class II molecules calculated by APBS electrostatics (positive charge, blue; negative charge, red) with P1, P9 and P10 pockets indicated, and with peptides in sticks. (B) side view of peptide in sticks with amino acids indicated and with pockets as surfaces with $\mathrm{P} 1, \mathrm{P} 9$ and $\mathrm{P} 10$ pockets indicated, and with length between $\mathrm{C} \alpha$ of $\mathrm{P} 1$ and $\mathrm{P} 9$ or P10 shown (blue asterisks indicate that the side chains are not resolved). (C) 
291 edge-on view of peptide C $\alpha$ backbone, with arrow indicating departure of P4 in BL2*02

292 from the polyproline II helix. (D) schematic of H-bonds interacting with peptide main chain

293 atoms (cut-off of $3.2 \AA$ ) originally described for DR1*01 (solid lines) compared to BL2*19

294 (dashed lines) and BL2*02 (dotted lines); additional interactions subsequently found are

295 shown in Figs. S6-S8). (E) ribbon representation of class II molecule with superimposing

296 peptide C $\alpha$ backbones for BL2*02 (slate blue), BL2*19 (yellow) and DR1*01 (grey)

297 showing top view ( $\alpha 1$ domain above, $\beta 1$ domain below) and side view ( $\alpha 1$ domain shown, $298 \beta 1$ domain removed for clarity), and with arrow indicating departure of P4 in BL2*02 from 299 the polyproline II helix. (F) close-up view of class II molecules in ribbons with peptide $\mathrm{C} \alpha$ 300 backbones, and with the side chains for residues around pocket 4 and peptide P4 as sticks, 301 superimposing BL2*02 (slate blue) with BL2*19 (grey with yellow peptide) in left hand 302 panel and with DR1*01 (grey) in right hand panel. 
303

304

305

306

307

308

309

310

311

312

313

314

315

316

317

318

319

320

321

322

323

324

325

326

327

328

329

330

331

332

333

334

335

336

337

338

339

340

341

342

343

344

345

346

347

348

\section{Discussion}

The chicken MHC can determine life or death after infection from certain economicallyimportant pathogens, of which MDV is an iconic example. Infection of bursal B cells in culture allowed us to determine the peptides bound to class II molecules, the peptide motifs of the two class II molecules encoded by the B2 haplotype, the MDV genes that give rise to the pathogen peptides that are potential $\mathrm{T}$ cell epitopes, and an unexpected mode of peptide binding to the dominantly-expressed class II molecule of this haplotype.

The size distribution, raggedy ends, enrichment of proline in the N-terminal flanking region, and multiple amino acids for anchor positions of the peptides bound to the class II molecules of the chicken MHC B2 haplotype were expected from work on mammalian class II molecules, but there were surprises with the motifs. The BL1 molecule (composed of BLA $\alpha$ chain and BLB1 $\beta$ chain) has motif with large aliphatic residues at P1 and aromatic and large aliphatic residues at P9, but only a slight enrichment for basic amino acids in between without any obvious anchor residue preferences. The BL2 molecule (BLA $\alpha$ chain and BLB2 $\beta$ chain), which is the dominantly-expressed class II molecule in most tissues [26], has an unprecedented decamer core motif, with large aliphatic residues at P1 and P4, small and even acidic residues at P5, and large hydrophobic residues at P10.

It was also a surprise to find that, in this in vitro infection of chicken B cells, only four MDV genes gave rise to $77 \%$ (49/64) of the class II-bound peptide species from the pathogen and 44\% (10/23) of all the potential T cell epitopes found. In fact, epitopes from these four MDV genes were found in many of the samples, whereas the most peptides were found in only one sample and are likely to be very rare, so the impact of the epitopes from the four MDV genes will be much larger than the numbers suggest. The four genes all encode structural proteins present in the virion, three surface glycoproteins and one polytopic tegument protein (Table S1), but these genes are expressed early after infection of $\mathrm{B}$ cells [49]. There are many other proteins present in the virion, and many other proteins expressed early after infection $[14,16]$, so why these four proteins are the source of most presented peptides is not at all clear yet.

This dominance of just a few class II epitopes from a few MDV proteins stands in contrast to other human and mouse herpesviruses, for which polyclonal (and in some cases polyfunctional) $\mathrm{CD}^{+} \mathrm{T}$ cell responses to many codominant epitopes have been reported, with multiple epitopes within some proteins [50-52]. The situation may also be true for vaccina virus $[53,54]$, another virus with a similarly large DNA genome. However, this finding of few class II epitopes for MDV could fit with the existence of chicken MHC haplotypes that confer susceptibility, which would be difficult to explain with a larger number of $\mathrm{T}$ cell epitopes.

The overall structure of the chicken class II molecule is similar to that of mammals, which is perhaps not such a surprise given the high level of sequence identity, particularly in the BLA $\alpha$ chain [33]. Almost all the key features and residues involved in interactions with DM, CD4 and peptides are conserved. However, the details of the peptide binding to BL2*02 were unexpected, all deriving from a single amino acid polymorphism in the BLB2 $\beta$ chain. The small MHC residue Ser $\beta 78$ leads to a pocket which pulls in the side chain from peptide position $\mathrm{P} 4$, resulting in a crinkle in the peptide unlike the completely flat peptide in a polyproline II helix as is normally found. This crinkle pulls the C-terminus of the peptide towards the N-terminus, resulting in a shift of one peptide position along for 
the main chain interactions, the anchor residues (P1, P2, P4, P5, P8 and P10) and the side chains pointing up towards the T cell (P3, P6 and P9). It has long been known that differences in the size of a single class II side chain can have strong effects on which peptides are bound and thus on the subsequent functional effects, as in the example of the Val-Ile dimorphism of $\beta 89$ in DRB1 [55].

The MHC haplotype B2 is known to confer resistance to MD (as well as other common poultry pathogens, [7]). As mentioned above, a structure was very recently reported for a chicken class II molecule from B19 [43], a haplotype that is known to confer susceptibility to $\mathrm{MD}[13,44]$. This B19 molecule has a nonamer peptide motif, which leaves open the possibility that such a difference might contribute to the differences in resistance to MD. However, the chicken MHC (the BF-BL region) has low rates of recombination [56-58], meaning that a number of genes are inherited as haplotypes. Thus, much more work is required to determine whether class II molecules are important as suggested [23-25], along with the classical class I genes (BF1 and BF2), the NK receptor/ligand pair (BNK and Blec), and the butyrophilin homolog (BG1) which all have been proposed as candidates to explain the strong genetic associations with infectious pathogens [19-22].

No matter what the contribution of chicken class II molecules to differential resistance to MDV infection, the design and results of this study open the possibility of understanding $\mathrm{T}$ cell epitopes to generate improved vaccines for MDV as well as other economicallyimportant and zoonotic poultry pathogens $[6,8-11,17,18]$. Moreover, the results from this relatively simple system for chicken MHC haplotypes has relevance for human viral disease, given the class I molecules encoded by individual loci in mammals may function like the dominantly-expressed class I molecule of chickens [7]. 


\section{Methods}

\section{MDV infection of bursal B cells in culture}

Viruses. MDV reporter viruses expressing the green fluorescent protein (GFP) under the control of the herpes simplex virus 1 (HSV-1) thymidine kinase promotor were generated based on the very virulent RB-1B field strain (GenBank accession number EF523390) and the vaccine strain CVI988 (DQ530348). GFP was inserted into the bacterial artificial chromosome (BAC) backbone replacing the Eco-gpt gene [59]. BACs were confirmed by Illumina MiSeq sequencing to verify sequence integrity.

Chicken embryo cells (CEC) were isolated from 11-day-old VALO specific-pathogen-free (SPF) embryos (VALO Biomedia; Osterholz-Scharmbeck, Germany) as described previously [60]. CEC were maintained in minimal essential medium (MEM, PAN Biotech; Aidenbach, Germany) supplemented with 1-10\% fetal bovine serum, $100 \mathrm{U} / \mathrm{ml}$ penicillin and $100 \mu \mathrm{g} / \mathrm{ml}$ streptomycin (AppliChem; Darmstadt, Germany) at $37^{\circ} \mathrm{C}$ and $5 \% \mathrm{CO}_{2}$.

All recombinant GFP reporter viruses were reconstituted by transfection of fresh CEC with purified BAC DNA using $\mathrm{CaPO}_{4}$ transfection [61]. The viruses were propagated on $\mathrm{CEC}$ for up to nine passages, and infected cells were stored in liquid nitrogen.

Isolation and culture of bursal B cells. Fertilized eggs of M11 (B2/B2) chickens were kindly provided by Dr. S. Weigend (Federal Research Institute for Animal Health, Mariensee, Germany) and hatched at the Faculty for Veterinary Medicine, Munich. Birds were housed under conventional conditions in aviaries with groups up to 10 birds and received food and water ad libitum. Bursas were isolated from 6-8 week old birds, and cells were obtained by dissociation of the organs in PBS using a stainless-steel sieve. Leukocytes were isolated by density gradient centrifugation on Biocoll $(1.077 \mathrm{~g} / \mathrm{ml}$, Biochrom, Berlin, Germany).

B cells were cultured at $40{ }^{\circ} \mathrm{C}$ in Iscoves modified Dulbeccos's medium (IMDM), 100 $\mathrm{U} / \mathrm{ml}$ penicillin, $100 \mu \mathrm{g} / \mathrm{ml}$ streptomycin, $8 \%$ (vol/vol) fetal bovine serum (all Bio\&Sell, Nürnberg, Germany) and 2\% (vol/vol) chicken serum (ThermoFisher Scientific, Waltham, USA), with the addition of recombinant soluble chicken BAFF and chicken CD40L, as described $[36,62,63]$.

Infection of bursal B cells. For MDV infection, $1 \times 10^{7} \mathrm{~B}$ cells were co-cultured with $3 \times$ $10^{5}$ freshly-thawed MDV-infected CECs (representing an infectious dose between 0.5 to 1 $\mathrm{x} 10^{5}$ plaque-forming units) in $1 \mathrm{ml}$ in a 24 well plate. Up to $10^{9}$ cells were harvested 24 hours after infection, washed with PBS three times and frozen at $-80^{\circ} \mathrm{C}$. At this time point cultures contained $25-35 \%$ viable B cells and $10-15 \%$ of viable B cells were GFP positive (infected with MDV), as assessed by flow cytometry with the Fixable Viability Dye eFluor $^{\text {TM }} 780$ (Thermo Fisher Scientific) using a FACSCanto II flow cytometer and FACS DIVA and FlowJo software (BD, Heidelberg, Germany).

Ethical permission. Permission for the procedures involving animals was given by Landesamt für Gesundheit und Soziales (LAGeSo) in Berlin (approval number T0245/14) 
and in Munich (file number KVR-I/221-TA 160/13-He, Inst.-Nr. 01-17a) with organ sampling in accordance with the German Animal Welfare Act.

\section{Isolation of class II molecules and immunopeptidomics}

Isolation of peptides from class II molecules. As described $(37,64)$, frozen cells were thawed into $10 \mathrm{mM}$ CHAPS (AppliChem, St. Louis, MO) in PBS (Gibco, Carlsbad, CA) with complete protease inhibitor (Roche, Basel, Switzerland), and class II molecules were isolated by standard immunoaffinity purification using purified monoclonal antibody 2G11 [65] produced in-house and covalently linked to CNBr-activated Sepharose (GE Healthcare, Chalfont St Giles, UK). MHC-peptide complexes were eluted by repeated addition of $0.2 \%$ trifluoroacetic acid (TFA, Merck, Whitehouse Station, NJ). Peptides were purified by ultrafiltration using centrifugal filter units (Amicon; Millipore, Billerica, MA), desalted using ZipTip C18 pipette tips (Millipore) and eluted in $35 \mu 1$ 80\% acetonitrile (Merck), $0.2 \%$ TFA, then vacuum-centrifuged and resuspended in $25 \mu 11 \%$ acetonitrile, $0.05 \%$ TFA and stored at $-20^{\circ} \mathrm{C}$.

Analysis of peptides by $L C$ - and below MS/MS. Peptides were separated by reverse-phase liquid chromatography and analyzed from 2-3 technical replicates, with sample shares of $33 \%$ or $50 \%$ trapped on a $75 \mu \mathrm{m} \times 2 \mathrm{~cm}$ trapping column (Acclaim PepMap RSLC; Thermo Fisher) at $4 \mu \mathrm{l} / \mathrm{min}$ for $5.75 \mathrm{~min}$. Peptide separation was performed at $50^{\circ} \mathrm{C}$ and a flow rate of $175 \mathrm{nl} / \mathrm{min}$ on a $50 \mu \mathrm{m} \times 25 \mathrm{~cm}$ separation column (nano-UHPLC, UltiMate 3000 RSLCnano; Thermo Fisher, Waltham, MA) applying a gradient ranging from 2.4 to $32.0 \%$ of acetonitrile over the course of $90 \mathrm{~min}$. Samples were analyzed as previously described [66] using an online-coupled Orbitrap Fusion Lumos mass spectrometer (Thermo Fisher, Waltham, MA), implementing a top-speed CID method with survey scans at 120k resolution and fragment detection in the Orbitrap (OTMS2) at 60k resolution. The mass range was limited to $400-650 \mathrm{~m} / \mathrm{z}$ with precursors of charge states $2+$ and $3+$ eligible for fragmentation.

Database search and spectral annotation. LC-MS/MS results were processed using Proteome Discoverer (v.1.3 and 1.4; Thermo Fisher) to perform database search using the Sequest search engine (Thermo Fisher) with the chicken and appropriate MDV proteomes as reference database annotated by the UniProtKB/Swiss-Prot (www.uniprot.org), status April 2018. The search combined data of three technical replicates, was not restricted by enzymatic specificity, and oxidation of methionine residues was allowed as dynamic modification. Precursor mass tolerance was set to $5 \mathrm{ppm}$, and fragment mass tolerance to $0.02 \mathrm{Da}$. False discovery rate (FDR) was estimated using the Percolator node (67) and was limited to 5\%. Length of peptides was limited to 12-25 amino acids. Possible peptide motifs of peptides were grouped using GibbsCluster-2.0 (68), and Venn diagrams were done by BioVenn (69).

\section{Expression of class II molecules and structural determination}

Cell lines. Sf9 insect suspension cells (Spodoptera frugiperda female ovarian cell line, ATCC CRL-1711) were used for production of baculovirus and High Five insect suspension cells (Trichoplusia ni female ovarian cell line, GIBCO B85502) streptomycin 
458

459

460

461

462

463

464

465

466

467

468

469

470

471

472

473

474

475

476

477

478

479

480

481

482

483

484

485

486

487

488

489

490

491

492

493

494

495

496

497

498

499

500

501

502 were used for protein production, both grown in Insect-XPRESS Protein-free Insect Cell Medium (Lonza, BE12-730Q) supplemented with L-glutamine (to 1\%), $50 \mathrm{U} / \mathrm{ml}$ penicillin and $50 \mu \mathrm{g} / \mathrm{ml}$ streptomycin at $27^{\circ} \mathrm{C}$ with $135 \mathrm{rpm}$ shaking.

Cloning, protein expression and purification. For protein production and crystallography, the different constructs were cloned separately into the baculovirus insect cell expression vector, pFastBac1 (GIBCO 10360014), modified to contain an N-terminal GP67 secretion signal sequence (for amino acid sequences of each portion, see Fig. S9). For the BLA construct, the GP67 signal sequence was followed by the ectodomain of the $\alpha$-chain of

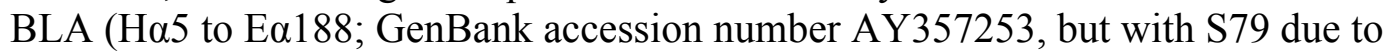
dimorphism noted in [33]), then a short Gly/Ser-linker (G4S), a c-fos dimerization domain [70], a two amino acid linker (GT), and an Avi-tag sequence for biotinylation. For the BLB2 constructs, the GP67 signal sequence was followed by a peptide sequence (described in Fig. S9), a 15 amino acid Gly/Ser-linker [3(G4S)], the ectodomain of the $\beta$-chain of BLB2 (Sß4 to K $\beta 198$; AB426141), a TEV-protease cleavage site, a c-jun dimerization domain [70], a Gly/Ser-linker [2(G4S)], a V5-tag and a 6x His-tag. Correct cloning was confirmed by DNA sequencing.

To generate bacmids, the constructs were transformed DH10Bac cells (GIBCO 10361012), plated out and clones grown up overnight. Bacmid DNA was subjected to PCR using M13 primers to confirm transposition of inserts, and then transfected into Sf9 cells as follows to generate P0 viral stocks. First, $20 \mu \mathrm{l}$ bacmid DNA and $15 \mu \mathrm{l}$ Fugene (Promega E2311) were each diluted into $600 \mu \mathrm{l}$ of Lonza Insect Xpress medium, mixed together and incubated at room temperature for 20 minutes and then $200 \mu \mathrm{l}$ of the mixture were transferred to a well of a 6 well plate containing $9 \times 10^{5} \mathrm{Sf} 9$ cells in $2 \mathrm{ml}$ antibiotics-free medium and incubated for 4- 6 days at $27^{\circ} \mathrm{C}$. The cell medium containing baculovirus was collected, passed through a $0.2 \mu \mathrm{m}$ filter (Sartorius $16532-\mathrm{K}$ ), and then this P0 stock was used to amplify the number of viruses to give the P1 stock as follows. First, $1 \mathrm{ml} \mathrm{P0} \mathrm{stock} \mathrm{was} \mathrm{added} \mathrm{to} 50 \mathrm{ml}$ of $2 \times 10^{6} \mathrm{Sf} 9$ cells $/ \mathrm{ml}$ in suspension and cultured at $27^{\circ} \mathrm{C}$ for 48 hours with shaking at 135 $\mathrm{rpm}$, then the cells were pelleted, and the culture media was filtered as above. Both P0 and $\mathrm{P} 1$ viral stocks were stored at $4^{\circ} \mathrm{C}$ until needed.

High Five cells were grown in 0.6 L medium in $2 \mathrm{~L}$ flasks and transduced with 6-10 ml P1 stock. 48-72 hours after infection, culture media was collected and incubated overnight at $4^{\circ} \mathrm{C}$ with nickel-Sepharose Excel (GE Healthcare 17-3712-01). His-tagged proteins were eluted from the nickel-Sepharose with $1 \mathrm{M}$ imidazole in TrisCl $\mathrm{pH} 8.5$, then purified by FPLC size-exclusion chromatography using Superdex S200 in $100 \mathrm{mM}$ TrisCl pH 8.5, and subjected to endoproteinase Glu-C (V8 Protease, Sigma) cleavage at $37^{\circ} \mathrm{C}$ overnight to remove C-terminal tags and dimerization domains, with successful proteolysis confirmed by size shift in SDS-PAGE. The proteins were again purified as above using Superdex $\mathrm{S} 200$ in $25 \mathrm{mM}$ TrisCl pH 8.5, and then concentrated using Amicon Ultra (with 3,000 Da molecular weight cut-off, Merck UFC8003) to 3-12 $\mathrm{mg} / \mathrm{ml}$ as determined using a nanodrop spectrophotometer.

Crystallization and structure determination. Crystallization conditions were screened using the PEGs II suite (Qiagen) at $20^{\circ} \mathrm{C}$, with $10.45 \mathrm{mg} / \mathrm{mL}$ protein in $25 \mathrm{mM}$ TrisCl $\mathrm{pH} 8.5$ mixed at $1: 1$ or $1: 2$ with mother liquor to give $0.6-0.9 \mu$ sitting drops. The protein complex BL2*02 with the peptide QIESLSLNGVPNIFLSTKA from MDV protein gE crystalized in $100 \mathrm{mM}$ TrisCl pH 8.5, $200 \mathrm{mM}$ sodium acetate, and 30 \% w/v PEG 4000. Crystals were 
503 cryo-cooled in mother liquor supplemented with $10-35 \%(\mathrm{v} / \mathrm{v})$ glycerol before data

504 collection.

505 Diffraction data was collected remotely on the I04-1 beamline (Diamond Light Source,

506 Oxford UK) at a wavelength of $0.978 \AA$. Data reduction and scaling were performed using

507 XDS (71) and SCALA (72). The crystal of the BL2*02 belongs to the C 121 space group,

508 and the structure was solved by basic molecular replacement deploying Phaser from the

509 CCP4i package (73) using HLA-DR1 (4X5W) as the search model (74). Further rounds of

510 manual model building and refinement were done using Coot (75) and Phenix (76). Further

511 details about collection and refinement are shown in Table S2. The structure was deposited

512 in the Protein Database (PDB) on 14 October 2019 and assigned accession number 6T3Y.

513 Interaction analysis. LigPlot+ (77) was used to calculate the potential interactions from the

514 crystal structure. Unless stated otherwise, the maximum hydrogen-acceptor distance was set

515 to $2.70 \AA$ and the maximum donor-acceptor distance was set to $3.35 \AA$. The minimum and

516 the maximum contact distances of hydrophobic residue to any contact were set to $2.90 \AA$

517 and $3.90 \AA$, respectively. PyMOL (The PyMOL Molecular Graphics System, Version 2.0

518 Schrödinger, LLC) was used to display and analyze the structural data visually.

519 Differential scanning fluorimetry. Differential scanning fluorimetry was performed using a

520 CFX Connect real time PCR thermal cycler (Biorad) set to Fluorescence Resonance Energy

521 Transfer (FRET) scan mode. SYPRO orange (Invitrogen S6651) was diluted to 1:500 in 25

$522 \mathrm{mM}$ TrisCl pH 8 and $12.5 \mu \mathrm{L}$ mixed with $12.5 \mu \mathrm{L} 10 \mu \mathrm{M}$ protein in $25 \mathrm{mM}$ TrisCl $\mathrm{pH} 8$ in

523 each well of a 96 well plate, with buffer alone serving as negative control. The samples

524 were scanned every $0.5^{\circ} \mathrm{C}$ from 25 to $95^{\circ} \mathrm{C}$. Data analysis was performed in Prism

525 (GraphPad). 
bioRxiv preprint doi: https://doi.org/10.1101/2020.11.27.400937; this version posted November 27,2020 . The copyright holder for this preprint (which was not certified by peer review) is the author/funder, who has granted bioRxiv a license to display the preprint in perpetuity. It is made available under aCC-BY 4.0 International license.

\section{Acknowledgments}

527

528

529

530

531

532
We thank Dr. Alicia Martin Lopez for constructs that were the source of the BLA and BLB sequences, Dr. Paul Brear of the Crystallography facility in the Department of

Biochemistry at the University of Cambridge for much help, the staff of beamline I04 at the Diamond Light Source for help with data collection, and Drs. Clive Tregaskes and Hassnae Afrache for critical reading. 


\section{References}

1. Forum on Microbial Threats; Board on Global Health; Institute of Medicine. Emerging Viral Diseases: The One Health Connection: Workshop Summary. Washington (DC): National Academies Press (US); 2015 Mar 19. PMID: 25834866.

2. Crawford R, Rutz DC, Evans DP. 'Between Combat boots and Birkenstocks'Lessons from HIV/AIDS, SARS, H1N1 and Ebola. Public Health. 2016 Dec;141:186-191. doi: 10.1016/j.puhe.2016.09.018. PMID: 27931998.

3. Goodnow CC. COVID-19, varying genetic resistance to viral disease, and immune tolerance checkpoints. Immunol Cell Biol. 2020 Oct 28. doi: 10.1111/imcb.12419. PMID: 33113212.

4. Trowsdale J, Knight JC. Major histocompatibility complex genomics and human disease. Annu Rev Genomics Hum Genet. 2013;14:301-323. doi: 10.1146/annurevgenom-091212-153455. PMID: 23875801.

5. Djaoud Z, Parham P. HLAs, TCRs, and KIRs, a triumvirate of human cell-mediated immunity. Annu Rev Biochem. 2020 Jun 20;89:717-739. doi: 10.1146/annurevbiochem-011520-102754. PMID: 32569519.

6. Miller M, Taylor R. Brief review of the chicken Major Histocompatibility Complex: the genes, their distribution on chromosome 16, and their contributions to disease resistance. Poult Sci. 2016; 95: 375-392. doi: 10.3382/ps/pev379. PMID: 26740135.

7. Kaufman J. Generalists and Specialists: A new view of how MHC class I molecules fight infectious pathogens. Trends Immunol. 2018; 39: 367-379. doi: 10.1016/j.it.2018.01.001. PMID: 29396014.

8. Reagan RL, Brueckner AL. Electron microscope studies of four strains of infectious bronchitis virus. Am J Vet Res. 1952 Jul;13(48):417-48. PMID: 12976644.

9. Su S, Gu M, Liu D, Cui J, Gao GF, Zhou J, Liu X. Epidemiology, Evolution, and Pathogenesis of H7N9 Influenza Viruses in Five Epidemic Waves since 2013 in China. Trends Microbiol. 2017 Sep;25(9):713-728. doi: 10.1016/j.tim.2017.06.008. PMID: 28734617.

10. Zhou X, Zhang Y, Shen C, Liu A, Wang Y, Yu Q, Guo F, Clements ACA, Smith C, Edwards J, Huang B, Soares Magalhães RJ. Knowledge, attitudes, and practices associated with avian influenza along the live chicken market chains in Eastern China: A cross-sectional survey in Shanghai, Anhui, and Jiangsu. Transbound Emerg Dis. 2019 Jul;66(4):1529-1538. doi: 10.1111/tbed.13178. PMID: 30891947.

11. Kennedy DA, Dunn JR, Dunn PA, Read AF. An observational study of the temporal and spatial patterns of Marek's-disease-associated leukosis condemnation of young 
chickens in the United States of America. Prev Vet Med. 2015 Jul 1;120(3-4):328335. doi: 10.1016/j.prevetmed.2015.04.013. PMID: 25998661

12. Calnek B. Pathogenesis of Marek's disease virus infection. Curr Top Microbiol Immunol. 2001; 255: 25-55. PMID: 11217426.

13. Plachy J, Pink J, Hála K. Biology of the chicken MHC (B complex). Crit Rev Immunol. 1992; 12: 47-79. PMID: 1358107.

14. Osterrieder N, Kamil J, Schumacher D, Tischer B, Trapp S. Marek's disease virus: from miasma to model. Nat Rev Microbiol. 2006; 4: 283-294. doi: 10.1038/nrmicro1382. PMID: 16541136.

15. Reddy S, Izumiya Y, Lupiani B. Marek's disease vaccines: Current status, and strategies for improvement and development of vector vaccines. Vet Microbiol 2017; 206: 113-120. doi: 10.1016/j.vetmic.2016.11.024. PMID: 28038868.

16. Bertzbach L, Conradie A, You Y, Kaufer B. Latest Insights into Marek's disease virus pathogenesis and tumorigenesis. Cancers (Basel). 2020; 12: 647. doi: 10.3390/cancers 12030647. PMID: 32164311

17. Witter R. Increased virulence of Marek's disease virus field isolates. Avian Dis. 1997; 41: 149-163. PMID: 9087332.

18. Read A, Baigent S, Powers C, Kgosana L, Blackwell L, Smith LP, et al. Imperfect vaccination can enhance the transmission of highly virulent pathogens. PLoS Biol. 2015; 13: e1002198. doi: 10.1371/journal.pbio.1002198. PMID: 26214839.

19. Koch M, Camp S, Collen T, Avila D, Salomonsen J, Wallny HJ, et al. Structures of an MHC class I molecule from B21 chickens illustrate promiscuous peptide binding. Immunity. 2007; 27: 885-899. doi:10.1016/j.immuni.2007.11.007. PMID: 18083574.

20. Chappell P, el Meziane K, Harrison M, Magiera Ł, Hermann C, Mears L, et al. Expression levels of MHC class I molecules are inversely correlated with promiscuity of peptide binding. eLIFE. 2015; 4: e05345. doi: 10.7554/eLife.05345. PMID: 25860507.

21. Rogers S, Kaufman J. High allelic polymorphism, moderate sequence diversity and diversifying selection for B-NK but not B-lec, the pair of lectin-like receptor genes in the chicken MHC. Immunogenetics. 2008; 60: 461-475. doi: 10.1007/s00251008-0307-1. PMID: 18574582.

22. Goto R, Wang Y, Taylor R, Wakenell P, Hosomichi K, Shiina T, et al. BG1 has a major role in MHC-linked resistance to malignant lymphoma in the chicken. Proc Natl Acad Sci USA. 2009; 106: 16740-16755. doi: 10.1073/pnas.0906776106. PMID: 19805366. 
23. Haeri M, Read L, Wilkie B, Sharif S. Identification of peptides associated with chicken major histocompatibility complex class II molecules of B21 and B19 haplotypes. Immunogenetics. 2005; 56: 854-859. doi: 10.1007/s00251-004-0760-4. PMID: 15650875.

24. Cumberbatch J, Brewer D, Vidavsky I, Sharif S. Chicken major histocompatibility complex class II molecules of the B haplotype present self and foreign peptides. Anim Genet. 2006; 37: 393-396. doi: 10.1111/j.1365-2052.2006.01459.x. PMID: 16879355.

25. Niikura M, Kim T, Hunt H, Burnside J, Morgan R, Dodgson J, et al. Marek's disease virus up-regulates major histocompatibility complex class II cell surface expression in infected cells. Virology. 2007; 359: 212-219. doi: 10.1016/j.virol.2006.09.010. PMID: 17028059.

26. Parker A, Kaufman J. What chickens might tell us about the MHC class II system. Curr Opin Immunol. 2017; 46: 23-29. doi: 10.1016/j.coi.2017.03.013. PMID: 28433952.

27. Stern L, Brown J, Jardetzky T, Gorga J, Urban R, Strominger JL, et al. Crystal structure of the human class II MHC protein HLA-DR1 complexed with an influenza virus peptide. Nature. 1994; 368: 215-221. doi: 10.1038/368215a0. PMID: 8145819.

28. Yaneva R, Schneeweiss C, Zacharias M, Springer S. Peptide binding to MHC class I and II proteins: new avenues from new methods. Mol Immunol. 2010; 47: 649657. doi: 10.1016/j.molimm.2009.10.008. PMID: 19910050.

29. Pos W, Sethi D, Call M, Schulze M, Anders A, Pyrdol J, et al. Crystal structure of the HLA-DM-HLA-DR1 complex defines mechanisms for rapid peptide selection. Cell. 2012; 151; 1557-1568. doi: 10.1016/j.cell.2012.11.025. PMID: 23260142.

30. Yin Y, Wang X, Mariuzza R. Crystal structure of a complete ternary complex of Tcell receptor, peptide-MHC, and CD4. Proc Natl Acad Sci USA. 2012; 109: 54055410. doi: 10.1073/pnas.1118801109. PMID: 22431638.

31. Wearsch P, Peaper D, Cresswell P. Essential glycan-dependent interactions optimize MHC class I peptide loading. Proc Natl Acad Sci USA. 2011; 108: 49504955. doi: 10.1073/pnas.1102524108. PMID: 21383180.

32. Gao G, Tormo J, Gerth U, Wyer J, McMichael A, Stuart D, et al. Crystal structure of the complex between human CD8alpha(alpha) and HLA-A2. Nature. 1997; 387: 630-634. doi: 10.1038/42523. PMID: 9177355.

33. Salomonsen J, Marston D, Avila D, Bumstead N, Johansson B, Juul-Madsen H, et al. The properties of the single chicken MHC classical class II alpha chain (B-LA) gene indicate an ancient origin for the DR/E-like isotype of class II molecules. Immunogenetics. 2003; 55: 605-614. doi: 10.1007/s00251-003-0620-7. PMID: 14608490. 
34. Pharr G, Dodgson J, Hunt H, Bacon L. Class II MHC cDNAs in $15 \mathrm{I} 5$ B-congenic chickens. Immunogenetics. 1998; 47: 350-354. doi: 10.1007/s002510050369. PMID: 9510552.

35. Jacob J, Milne S, Beck S, Kaufman J. The major and a minor class II beta-chain (BLB) gene flank the tapasin gene in the B-F /B-L region of the chicken major histocompatibility complex. Immunogenetics. 2000; 51: 138-147. doi: 10.1007/s002510050022. PMID: 10663576.

36. Schermuly J, Greco A, Härtle S, Osterrieder N, Kaufer B, Kaspers B. In vitro model for lytic replication, latency, and transformation of an oncogenic alphaherpesvirus. Proc Natl Acad Sci USA. 2015; 112: 7279-7284. doi: 10.1073/pnas.1424420112. PMID: 26039998.

37. Nelde A, Kowalewski D, Stevanović S. Purification and identification of naturally presented MHC class I and II ligands. Methods Mol Biol. 2019; 1988: 123-136. doi: 10.1007/978-1-4939-9450-2_10. PMID: 31147937.

38. Purcell A, Ramarathinam S, Ternette N. Mass spectrometry-based identification of MHC-bound peptides for immunopeptidomics. Nat Protoc. 2019; 14: 1687-1707. doi: 10.1038/s41596-019-0133-y. PMID: 31092913.

39. Lee L, Powell P, Rennie M, Ross L, Payne L. Nature of genetic resistance to Marek's disease in chickens. J Natl Cancer Inst. 1981; 66: 789-796. PMID: 6262555.

40. Schat K, Calnek B, Fabricant J, Abplanalp H. Influence of oncogenicity of Marek's disease virus on evaluation of genetic resistance. Poult Sci. 1981; 60: 259-266. doi: 10.3382/ps.0602559. PMID: 6283507.

41. Rispens B, van Vloten H, Mastenbroek N, Maas H, Schat K. Control of Marek's disease in the Netherlands. I. Isolation of an avirulent Marek's disease virus (strain CVI 988) and its use in laboratory vaccination trials. Avian Dis. 1972; 16: 108-125. PMID: 4337307.

42. Zoorob R, Béhar G, Kroemer G, Auffray C. Organization of a functional chicken class II B gene. Immunogenetics. 1990; 31: 179-187. doi: 10.1007/BF00211553. PMID: 1969383.

43. Zhang L, Li X, Ma L, Zhang B, Meng G, Xia C. A newly recognized pairing mechanism of the $\alpha$ - and $\beta$-chains of the chicken peptide-MHC class II complex. J Immunol. 2020; 204: 1630-1640. doi: 10.4049/jimmunol.1901305. PMID: 32034060 .

44. Cole R. Studies on genetic resistance to Marek's disease. Avian Dis. 1968; 12; 9-28. PMID: 5643702. 
45. Kaufman J, Salomonsen J, Flajnik M. Evolutionary conservation of MHC class I and class II molecules--different yet the same. Semin Immunol. 1994; 6: 411-424. doi: 10.1006/smim.1994.1050. PMID: 7654997.

46. Xiao J, Xiang W, Zhang Y, Peng W, Zhao M, Niu L, et al. An invariant arginine in common with MHC Class II allows extension at the C-terminal end of peptides bound to chicken MHC class I. J Immunol. 2018; 201: 3084-3095. doi: 10.4049/jimmunol.1800611. PMID: 30341185.

47. Zavala-Ruiz Z, Strug I, Walker B, Norris P, Stern L. A hairpin turn in a class II MHC-bound peptide orients residues outside the binding groove for T cell recognition. Proc Natl Acad Sci USA. 2004; 101: 13279-13284. doi: 10.1073/pnas.0403371101. PMID: 15331779.

48. Zavala-Ruiz Z, Strug I, Anderson M, Gorski J, Stern L. A polymorphic pocket at the P10 position contributes to peptide binding specificity in class II MHC proteins. Chem Biol. 2004; 11: 1395-1402. doi: 10.1016/j.chembiol.2004.08.007. PMID: 15489166.

49. Bertzbach L, Pfaff F, Pauker V, Kheimar A, Höper D, Härtle S, et al. The transcriptional landscape of Marek's disease virus in primary chicken B cells reveals novel splice variants and genes. Viruses. 2019; 11: 264. doi: 10.3390/v11030264. PMID: 30884829.

50. Long H, Leese A, Chagoury O, Connerty S, Quarcoopome J, Quinn L, et al. Cytotoxic CD4+ T cell responses to EBV contrast with CD8 responses in breadth of lytic cycle antigen choice and in lytic cycle recognition. J Immunol. 2011; 187: 92101. doi: 10.4049/jimmunol.1100590. PMID: 21622860.

51. Freeman M, Burkum C, Cookenham T, Roberts A, Lanzer K, Huston G, et al. CD4 $\mathrm{T}$ cells specific for a latency-associated $\gamma$-herpesvirus epitope are polyfunctional and cytotoxic. J Immunol. 2014; 193: 5827-5834. doi: 10.4049/jimmunol.1302060. PMID: 25378595.

52. Nastke M, Becerra A, Yin L, Dominguez-Amorocho O, Gibson L, Stern L, et al. Human CD4+ T cell response to human herpesvirus 6. J Virol. 2012; 86: 47764792. doi: 10.1128/JVI.06573-11. PMID: 22357271.

53. Moutaftsi M, Bui H, Peters B, Sidney J, Salek-Ardakani S, Oseroff C, et al. Vaccinia virus-specific CD4+ T cell responses target a set of antigens largely distinct from those targeted by CD8+ T cell responses. J Immunol. 2007; 78: 68146820. doi: 10.4049/jimmunol.178.11.6814. PMID: 17513729.

54. Calvo-Calle J, Strug I, Nastke M, Baker S, L. Stern L. Human CD4+ T cell epitopes from vaccinia virus induced by vaccination or infection. PLoS Pathog. 2007; 3: 1511-1529. doi: 10.1371/journal.ppat.0030144. PMID: 17937498.

55. Demotz S, Barbey C, Corradin G, Amoroso A, Lanzavecchia A. The set of naturally processed peptides displayed by DR molecules is tuned by polymorphism of residue 
86. Eur J Immunol. 1993; 23: 425-432. doi: 10.1002/eji.1830230219. PMID: 7679644.

56. Skjødt K, Koch C, Crone M, Simonsen M. Analysis of chickens for recombination within the MHC (B-complex). Tissue Antigens 25, 278-282 (1985). doi: 10.1111/j.1399-0039.1985.tb00450.x. PMID: 4024061.

57. Hála K, Chaussé A, Bourlet Y, Lassila O, Hasler V, Auffray C. Attempt to detect recombination between B-F and B-L genes within the chicken B complex by serological typing, in vitro MLR, and RFLP analyses. Immunogenetics. 1988; 28: 433-438. doi: 10.1007/BF00355375. PMID: 2903118.

58. Fulton J, McCarron A, Lund A, Pinegar K, Wolc A, Chazara O, et al. A highdensity SNP panel reveals extensive diversity, frequent recombination and multiple recombination hotspots within the chicken major histocompatibility complex B region between BG2 and CD1A1. Genet Sel Evol. 2016; 48: 1. doi: 10.1186/s12711-015-0181-x. PMID: 26743767.

59. Bertzbach L, van Haarlem D, Härtle S, Kaufer B, Jansen C. Marek's disease virus infection of natural killer cells. Microorganisms. 2019; 7: 588. doi: 10.3390/microorganisms7120588. PMID: 31757008.

60. Schat K, Purchase H. "Cell-culture Methods" In A laboratory manual for the isolation and identification of avian pathogens, 4th edition (American Association of Avian Pathologists, Kennett Square, PA, USA, 1998).

61. Morgan RW, Cantello JL, McDermott CH. Transfection of chicken embryo fibroblasts with Marek's disease virus DNA. Avian Dis. 1990; 34: 345-351. PMID: 2164390.

62. Kothlow S, Morgenroth I, Graef Y, Schneider K, Riehl I, Staeheli P, et al. Unique and conserved functions of B cell-activating factor of the TNF family (BAFF) in the chicken. Int Immunol. 2007; 19: 203-215. doi: 10.1093/intimm/dxl137. PMID: 17220480 .

63. Tregaskes CA, Glansbeek HL, Gill AC, Hunt LG, Burnside J, Young JR. Conservation of biological properties of the CD40 ligand, CD154, in a nonmammalian vertebrate. Dev Comp Immunol. 2005; 29: 361-374. doi: 10.1016/j.dci.2004.09.001. PMID: 15859239.

64. Falk K, Rotzschke O, Stevanović S, Jung G, Rammensee H-G. Allele-specific motifs revealed by sequencing of self-peptides eluted from MHC molecules. Nature. 1991; 351: 290-296. doi: 10.1038/351290a0. PMID: 1709722.

65. Crone M, Simonsen M, Skjødt K, Linnet K, Olsson L. Mouse monoclonal antibodies to class I and class II antigens of the chicken MHC. Immunogenetics. 1985; 21: 181-187. doi: 10.1007/BF00364870. PMID: 3980052. 
66. Ghosh A, Gauger M, Marcu A, Nelde A, Denk M, Schuster H, et al. Guidance Document: validation of a high-performance liquid chromatography-tandem mass spectrometry immunopeptidomics assay for the identification of HLA class I ligands suitable for pharmaceutical therapies. Molec Cell Prot. 2020; 19: 432-443. doi: 10.1074/mcp.C119.001652. PMID: 31937595.

67. Kall L, Canterbury JD, Weston J, Noble WS, MacCoss MJ. Semi-supervised learning for peptide identification from shotgun proteomics datasets. Nat Methods. 2007; 4: 923-925. doi: 10.1038/nmeth1113. PMID: 17952086.

68. Andreatta M, Alvarez B, Nielsen M. GibbsCluster: unsupervised clustering and alignment of peptide sequences. Nucleic Acids Res. 2017; 45: W458-463. doi: 10.1093/nar/gkx248. PMID: 28407089.

69. Hulsen T, de Vlieg J, Alkema W. BioVenn - a web appliaction for the comparison and visualization of biological lists usnig area-proportional Venn diagrams. BMC Genomics. 2008; 9: 488. doi: 10.1186/1471-2164-9-488. PMID: 18925949.

70. Kalandadze A, Galleno M, Foncerrada L, Strominger J, Wuchterpfennig K. Expression of recomginant HLA-DR2 molecules. Replacement of the hydrophobic transmembrane region by a leucine zipper dimerization motif allows the assembly and secretion of soluble DR alpha beta heterodimers. J Biol Chem. 1996; 271: 20156-20162. doi: 10.1074/jbc.271.33.20156. PMID: 8702739.

71. Kabsch W. XDS. Acta Crystallogr D (Biol Crystallogr). 2010; 66: 125-132. doi: 10.1107/S0907444909047337. PMID: 20124692.

72. Evans PR, Murshudov GN. How good are my data and what is the resolution? Acta Crystallogr D (Biol Crystallogr). 2013; 69: 1204-1214. doi: 10.1107/S0907444913000061. PMID: 23793146.

73. Winn MD, Ballard CC, Cowtan KD, Dodson EJ, Emsley P, Evans PR, et al. Overview of the CCP4 suite and current developments. Acta Crystallogr D (Biol Crystallogr). 2011; 67: 235-242. doi: 10.1107/S0907444910045749. PMID: 21460441.

74. Wieczorek M, Sticht J, Stolzenberg S, Günther S, Wehmeyer C, El Habre Z, et al. MHC class II complexes sample intermediate states along the peptide exchange pathway. Nat Commun 2016; 7: 13224. doi: 10.1038/ncomms13224. PMID: 27827392.

75. Emsley P, Lohkamp B, Scott WG, Cowtan K. Features and development of Coot. Acta Crystallogr D (Biol Crystallogr). 2010; 66: 486-501. doi: 10.1107/S0907444910007493. PMID: 20383002.

76. Adams PD, Afonine PV, Bunkóczi G, Chen VB, Davis IW, Echols N, et al. PHENIX: a comprehensive Python-based system for macromolecular structure solution. Acta Crystallographica D (Biological Crystallogr). 2010; 66(Pt 2): 213221. doi: 10.1107/S0907444909052925. PMID: 20124702. 
bioRxiv preprint doi: https://doi.org/10.1101/2020.11.27.400937; this version posted November 27, 2020. The copyright holder for this preprint (which was not certified by peer review) is the author/funder, who has granted bioRxiv a license to display the preprint in perpetuity. It is made available under aCC-BY 4.0 International license.

871

872

873

874

77. Laskowski RA, Swindells MB. LigPlot+: multiple ligand-protein interaction diagrams for drug discovery. J Chem Inf Model. 2011; 51: 2778-2786. doi: 10.1021/ci200227u. PMID: 21919503. 


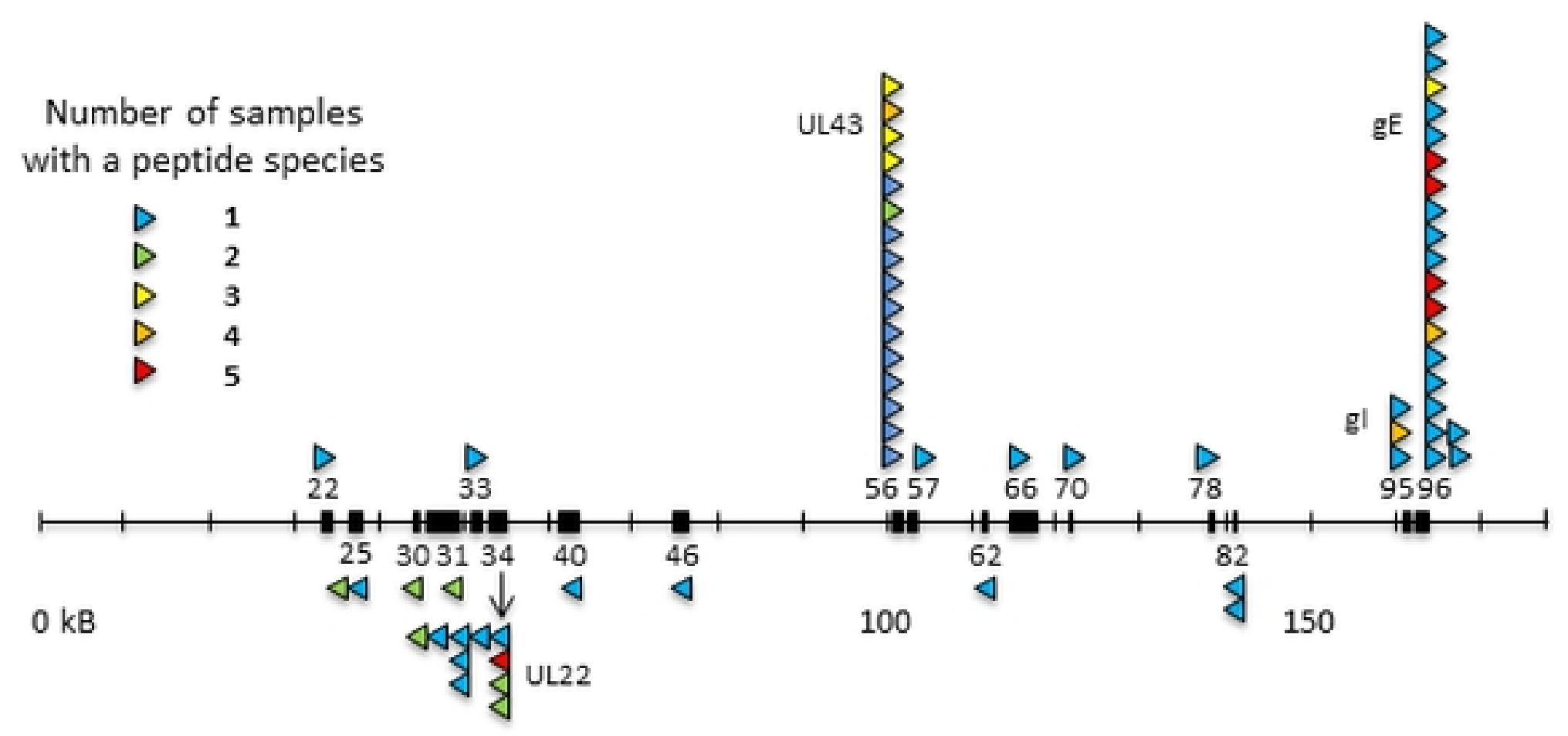

Figure 
A

Cluster 1

Cluster 2
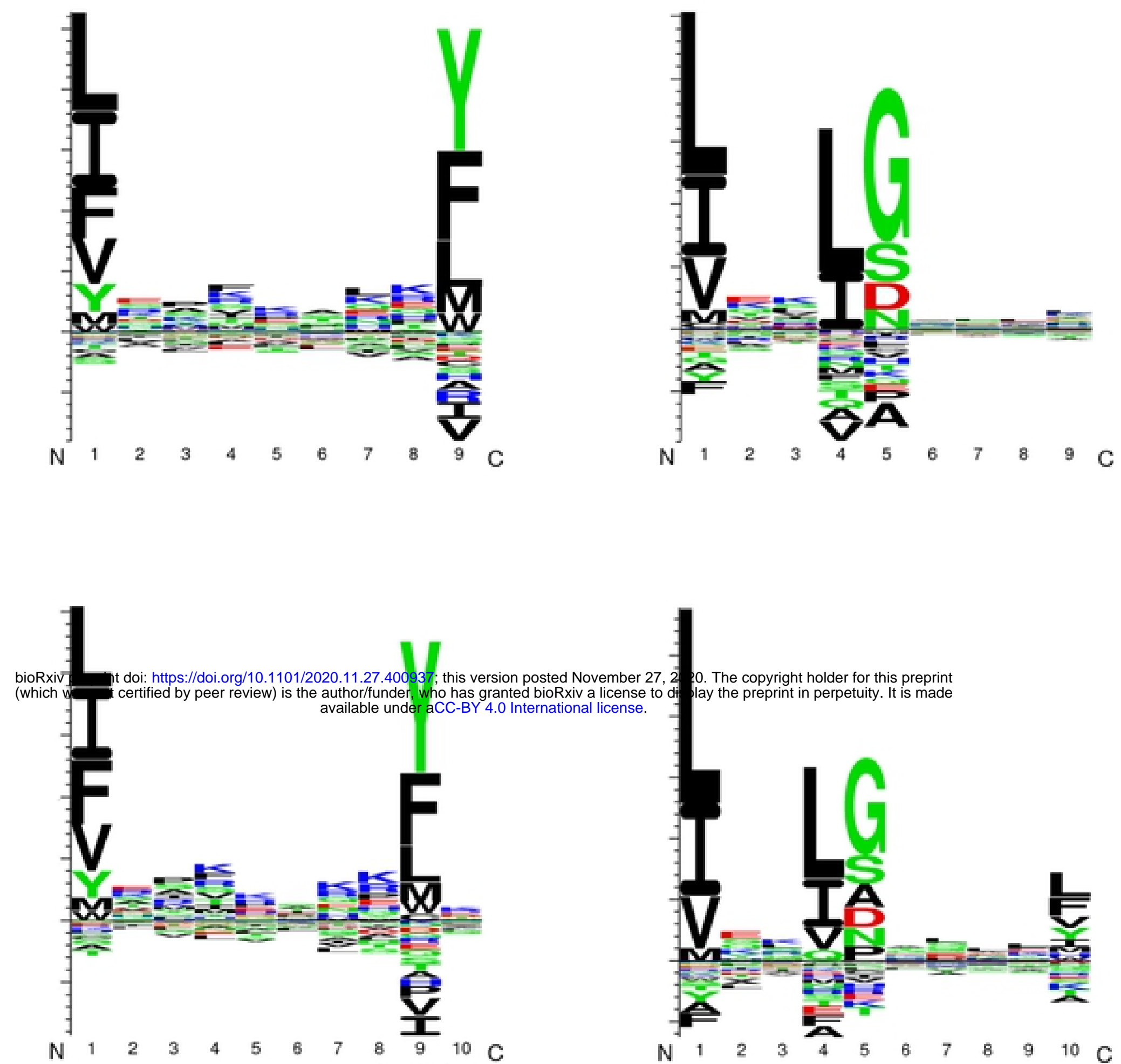

B

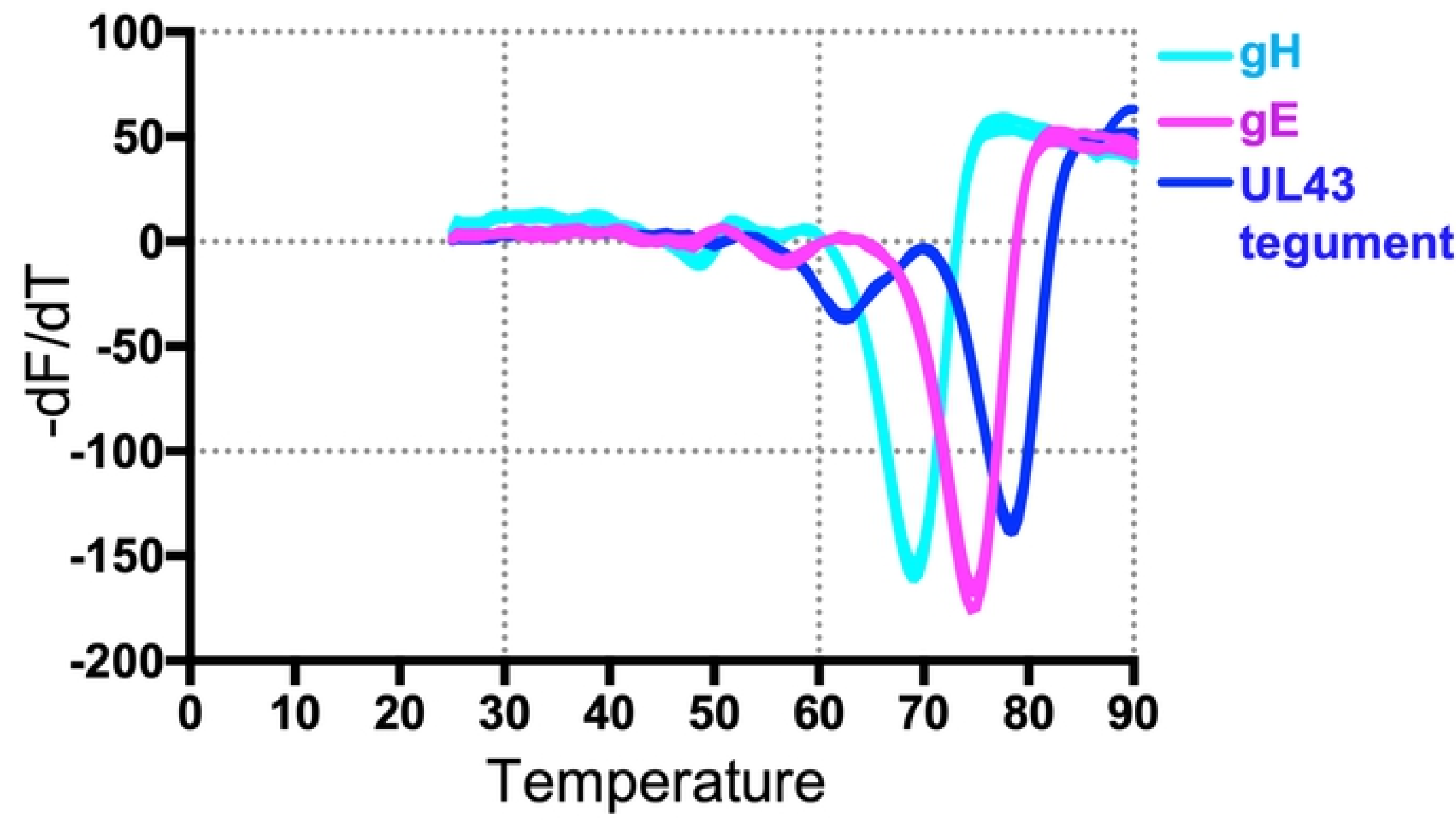

Figure 
A
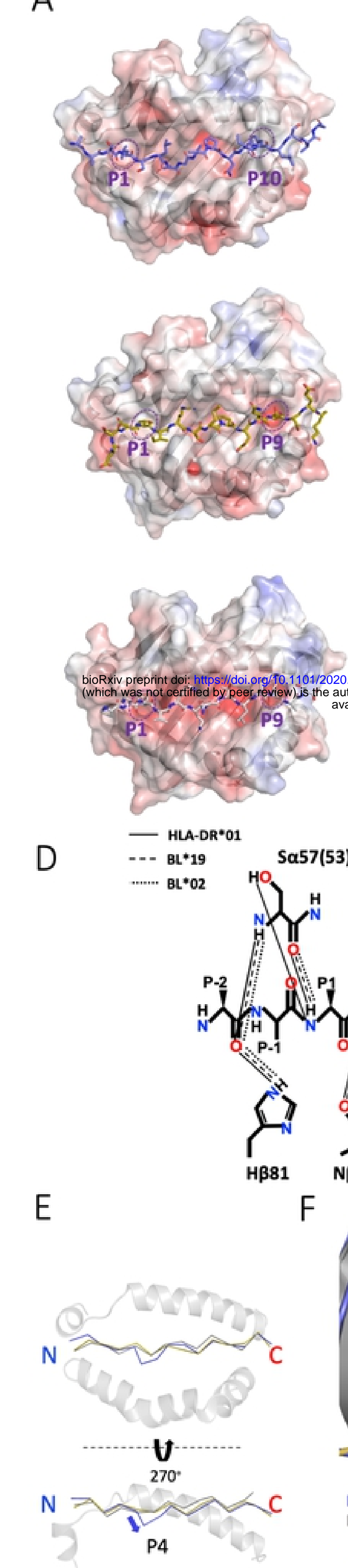

B
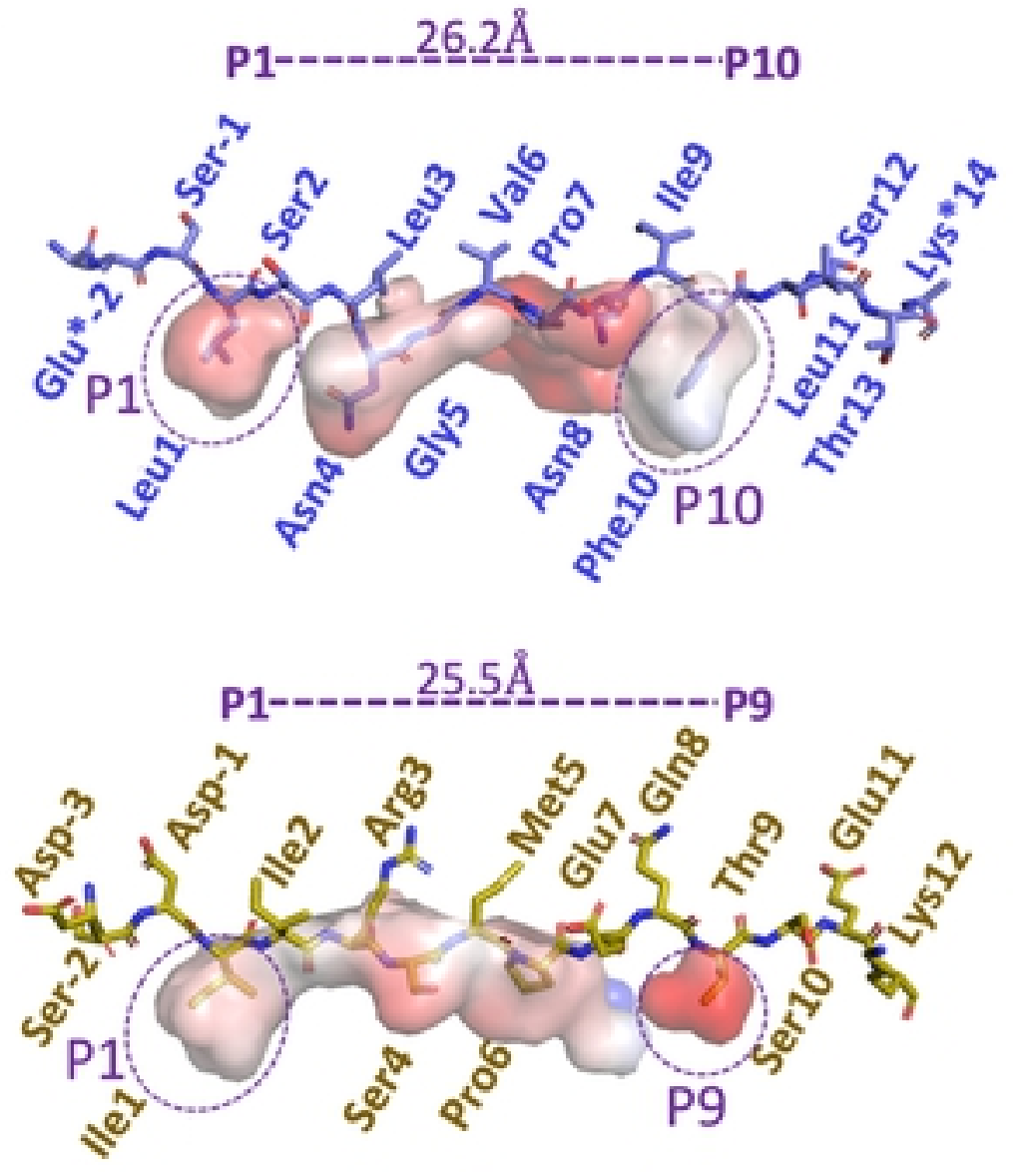

20
C
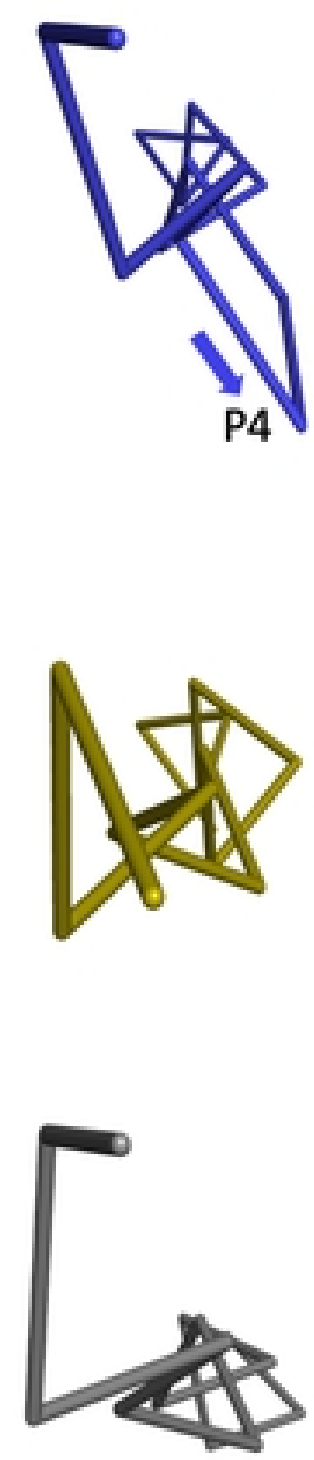

P1 